\title{
Introduction to a Comparative Study of the Right to Freedom of Thought
}

\author{
Bethany Shiner | ORCID: oooo-0oo2-6852-7816 \\ Lecturer in Law, School of Law, Middlesex University London, \\ London, UK; DPhil candidate, University of Oxford, Oxford, UK \\ b.shiner@mdx.ac.uk

\section{Patrick O'Callaghan} \\ Lecturer in Law, School of Law, University College Cork, Cork, Ireland \\ Patrick.ocallaghan@ucc.ie
}

\begin{abstract}
This is the introduction for the special issue on a comparative study of the right to freedom of thought across several jurisdictions including the UK, Ireland, Canada and the USA as well as the regional jurisdictions of the European Court of Human Rights and the Inter-American Court of Human Rights.
\end{abstract}

\section{Keywords}

freedom of thought - comparative - technology

The right to freedom thought is internationally recognised. It is enshrined in several international human rights treaties and various national bills of rights including Article 9 of the European Convention on Human Rights, Article 18 of the International Covenant on Civil and Political Rights, Article 13 American Convention on Human Rights, Article 2 of the Canadian Charter and Article 8 of the European Charter of Fundamental Rights. However, at least until recently, relatively little attention has been paid to the right in academic scholarship. Rather, the focus tends to be on the associated rights of freedom of religion, conscience, and expression. 
This special issue provides a comparative study of the right to freedom of thought across several jurisdictions primarily, but not exclusively, in the context of emerging technologies that are capable of monitoring, recording, reading and analysing human thought. The idea for a special issue emerged from a workshop on freedom of thought hosted by the editors at the International Association of Legal and Social Philosophy (IVR) annual conference in Lucerne, Switzerland in 2019. Contributors were asked to consider the status and scope of the right within their jurisdictions and evaluate the extent to which it protects individual thought, if at all. This study examines the right in the UK (Frank Cranmer), Ireland (Maria Cahill), Canada (Dwight Newman), the USA (John Francis and Leslie Francis) and within the regional jurisdictions of the European Court of Human Rights (Patrick O'Callaghan and Bethany Shiner) and the Inter-American Court of Human Rights (Cláudio de Oliveira Santos Colnago and Bethany Shiner). It remains a regret that we were unable to secure contributions from other continents. It was also unfortunate, but understandable, that contributors offering the German and Italian perspectives had to withdraw from the project due to the knock-on effects of the Covid-19 pandemic.

\section{Increasing Awareness of the Right to Freedom of Thought}

Since 2018, the right to freedom of thought has begun to gain some traction. In 2019, the Spanish Constitutional Court held that Spanish laws providing broad permission for political parties to collect and use voter data for campaign activities were unconstitutional because they violated the right to personal data protection, privacy and the 'right to ideological freedom' - which we can understand as a right to freedom of thought - and, importantly, the right to political participation. ${ }^{1}$ In this case, we see a recognition of the relationship between data collection, democratic participation and freedom of thought. Furthermore, there have been a number of policy papers arguing for better protection of freedom of thought, ${ }^{2}$ and new academic research has argued

1 STC 76/2019, de 22 de May 2019.

2 K. Jones. 2019. "Online Disinformation and Political Discourse: Applying a Human Rights Framework" Chatham House. Retrieved 1st February 2021 https://www.chathamhouse.org/ sites/default/files/2019-11-o5-Online-Disinformation-Human-Rights.pdf; S. Alegre 'Regulating around freedom in the 'forum internum" (2020) ERA Forum. October 202O. Retrieved 27th November 2020 https://link.springer.com/article/10.1007/s12027-020-00633-7; S. Alegre. 2020. 'Implications for the right to freedom of thought and the right to mental integrity of data sharing by mental health websites in the UK and EU Member States as evidenced in Privacy 
that the binary division between the forum internum and forum externum in relation to Article 9 ECHR has been wrongly understood. ${ }^{3}$ In addition, strategic litigation is being pursued as a way to help clarify the scope, limit and application of the right. ${ }^{4}$

There is growing awareness that the high rate of data collection and analysis for use in algorithmic decision-making in our everyday lives might undermine human autonomy - the basis, it may be argued, for the right to freedom of thought itself. That such concerns have particular potency in politics is also deserving of increased attention but there still has not been a single case before the European Court of Human Rights, the Inter-American Court of Human Rights nor the Supreme Courts of Canada, the US, the UK or Ireland that engages with the question of whether, and to what extent, algorithmic decision-making might be undermining the free exercise of our political agency. However, it is worth mentioning that a legal action has recently been launched in the UK, which may involve consideration of the means and effect of Russian interference in the UK-EU referendum through the manipulation of digital campaigns. ${ }^{5}$

There remains the argument that new rights are needed to protect human agency and cognitive autonomy in the face of emerging neuro-technologies that can intrude upon the forum internum. ${ }^{6}$ We do not believe this is necessary. Protection already exists in the form of the right to freedom of thought. It is argued in this special issue that this right can provide the protection sought and has the benefit of already sitting within developed legal frameworks with mechanisms for oversight and adjudication.

International's report - your Mental Health for Sale (2019)'. Digital Freedom Fund. Retrieved 1 February 2021 https://digitalfreedomfund.org/wp-content/uploads/2020/12/Susie-AlegreOpinion-The-Right-to-Freedom-of-Thought-and-Data-Sharing-from-Mental-Health-WebsitesFinal.pdf.

3 C. K. Roberts 'Reconceptualising the place of the forum internum and the forum externum in Article 9 of the European Convention on Human Rights' PhD Thesis, University of Bristol, 24 March 2020. Retrieved 27th November 2020 https://research-information.bris.ac.uk/en/ studentTheses/reconceptualising-the-place-of-the-forum-internum-and-forum-exter.

4 Digital Freedom Fund. 2020. 'Protecting Freedom of Thought in the Digital Age'. Retrieved 1 February 2021 https://digitalfreedomfund.org/protecting-freedom-of-thoughtin-the-digital-age/.

5 Leigh Day \& Co. 2020. 'Legal challenge to Government's failure to investigate Russian threat to UK democratic processes'. Retrieved 12 November 2020 https://www.leighday.co.uk/News/ Press-releases-2020/October-2020/Legal-challenge-to-Governments-failure-to-investig.

6 M. Ienca and R. Andorno, "Towards new human rights in the age of neuroscience and neurotechnology", Life Sciences, Society and Policy 13(5) (2017); P. Sommaggio et al, "Cognitive liberty. A first step towards a human neuro-rights declaration”, BioLaw Journal 3 (2017) 27-45. 


\section{Themes from the Contributions}

It is worth noting that two of the contributions are from national jurisdictions that have also signed up to the Council of Europe meaning those states are bound by Article 9 ECHR which states:

"1. Everyone has the right to freedom of thought, conscience and religion; this right includes freedom to change his religion or belief and freedom, either alone or in community with others and in public or private, to manifest his religion or belief, in worship, teaching, practice and observance.

2. Freedom to manifest one's religion or beliefs shall be subject only to such limitations as are prescribed by law and are necessary in a democratic society in the interests of public safety, for the protection of public order, health or morals, or for the protection of the rights and freedoms of others."

Moreover, both of the European contributions examine the national constitutional frameworks and the extent to which the domestic courts acknowledge the right to freedom of thought. In the UK, the jurisprudence is dominated by freedom of religion and philosophical belief under the Equality Act 2010 where there is no explicit mention of freedom of thought but there is some protection for the manifestation of certain thoughts. In Ireland, the constitutional doctrine of unenumerated rights is the means through which the right to freedom of thought may be recognised outside of Article 9 ECHR. The contribution on the right to freedom of thought within the ECHR looks beyond Article 9 to include Articles 8, 10 and $11 \mathrm{ECHR}$ in its analysis. This matrix of rights provides the conditions for the greatest enjoyment of the broad right to freedom of thought - a freedom that is enjoyed by the autonomous individual whose dignity is respected by the community. The ECHR contribution also tackles the question of when the right to freedom of thought ought to be regarded as offering absolute protection and when it offers qualified protection.

Freedom of thought is not recognised as an absolute right in any of the remaining jurisdictions featured in this special issue. The Canadian Constitution explicitly recognises the right to freedom of thought but not as an absolute right, for there is no such thing in that jurisdiction. In the USA, the right to freedom of thought is not explicitly mentioned but has been conflated with freedom of speech contained in the First Amendment to the US constitution. Article 13 of the American Convention on Human Rights has conceived of freedom of thought and expression more broadly than the ECHR as it states: 
"Everyone has the right to freedom of thought and expression. This right includes freedom to seek, receive, and impart information and ideas of all kinds, regardless of frontiers, either orally, in writing, in print, in the form of art, or through any other medium of one's choice."

Further, the Inter-American Court understands the right as containing both collective and individual rights: a dual dimension. The individual dimension consists of the right of each person to express her own thoughts, ideas and information, and a collective or social dimension consists of society's right to obtain and receive any information, to know the thoughts and ideas of others, and to be well-informed.

We hope that you enjoy reading the contributions to this special issue. 